Mini Review

\title{
Humic Substances Potential Use
}

\author{
Cleire Luciano Oliveira, ${ }^{1 *}$ Rose Luiza Moraes Tavares, ${ }^{1}$ Camila Santos Ferreira, ${ }^{1}$ Silvio Vasconcelos de Paiva Filho, ${ }^{1}$ \\ Diego Tolentino de Lima²
}

${ }^{1}$ Department of Soil Science, Universidad de Rio Verde, Brazil

${ }^{2}$ Instituto de Ciência e Tecnologia, Brazil

\begin{abstract}
There are studies that demonstrate several benefits of humic substances in agriculture. Based on this, this mini review aimed to present the main effects of the use of humic substances on the soil and the plant. For this, bibliographical references were used with an approach to humic substances on a world scale. Overall, the review showed that the chemical, microbiological and physical properties of humic substances can ensure an increase in agricultural productivity as a result of the benefits it promotes for the physical and chemical structure of the soil, for root development and plant metabolism, generating benefits in increasing agricultural productivity.
\end{abstract}

Keywords: Plants, Humic, Agriculture, Microbiological structure

\section{Introduction}

The agriculture in Brazil has been presenting a constant social and economic growth, with employment and income generation, in addition to significant increment of the gross domestic product (GDP)of the country. However, one of the current difficulties is the generation of technologieswith renewable and sustainable sources,which respect the environment and ecosystem. Among those concerns, soil fertility management has been the main target of national researches being developed in the country. As those researches advanced, there were several management system transitions with the aim to attain crop yield records and also in an attempt to resolve certain soil science paradigmssuch as production versusconservation.The Brazilian agriculture became highly competitive against international competitors. The firsttechnological leap was the No-tillage System, with preservation of residues (straw) for organic matter provision, with benefits that have been proven. Since then, theorganic matterhas been themain targetin terms of soil benefitsassociated with productivity and sustainable agriculture.
The organic matter, through its physical, chemical and biological effect on the soil, contributes to the maintenance of soil fertilityand, consequently, to plant development. ${ }^{1}$ During its decomposing process, there is formation ofnon-humic (proteins, carbohydrates, resins, lignin's) and humic substances. Humic substances can be divided into three main fractions: fulvic acids (FA), humic acids (HA) andhumin (HUM).Humic substances arebimolecular formed by complex polymeric organic compounds, includingpolyphenols, proteins, enzymes, lipids andpolysaccharides. ${ }^{2,3}$ The proportion of this fraction is 85 to $90 \%$ of thetotal organic carbon. ${ }^{4}$ Humic substanceshave a direct impact on the physical, chemical and microbiological structureof the environments where they are present, in addition to affecting plant metabolism and growth. ${ }^{5}$ Their main effects are the root system stimulation, influence on physical structure, substrate for microorganisms and nutrient availability.

Humic substances (HS) participate in important reactions that occur in thesoils, affecting fertility through the release of nutrients, detoxification of chemical elements, and enhancement of physical

\begin{tabular}{|l|l|}
\hline Quick Response Code: & *Corresponding author: Cleire Luciano Oliveira, Department of Soil Science, Universidad de \\
Rio Verde, Fazenda Fontes do Saber, s/n, Rio Verde - G0, 75901-970, Brazil \\
Received: 25 May, $2021 \quad$ Published: 21 June, 2021 \\
Citation: Cleire LO, Rose LMT, Camila SF, Silvio VPF, Diego TL. Humic Substances Potential Use. \\
Mod Tech Agri Horti Sci. 2021;1(1):1-3. DOI: 10.53902/MTAHS.2021.01.000502
\end{tabular}


and biological conditions. ${ }^{6}$ The most noticeable effects of humic and fulvic acidson the plant occur on the rootsystem, where they promote positive effect on growth, either by increasing the lateral root branches or increasing its biomass. Such effects are associated with the same effects produced by the auxin. This happens because the presence of humic acidsin thesoilstimulates theauxin synthesis or they act similarly to the auxin, since it results in cell expansion and elongation, promoting root growth. ${ }^{5}$

Fulvic acidsaresoluble in alkaline mediumand indiluted acid. They are mainly composed ofpolysaccharides, amino acids andphenolic compounds, which are more reactive than the other two fractionsdue to the larger amount of carboxylic and phenolic groupspresent in them.?

As to humic acids, theyareinsoluble in acid mediumand significantly help the soil structuringprocessesthrough aggregation and stimulation of root development. The use of humic and fulvic acids in agricultureis a recent topic and is going through an enhancement stage, with the performance of efficiency tests. Humic acidsare the most studied humic compounds and present poor solubilityin the acidic conditions normally found insoils. Thesecompounds are responsible for most of the CEC of organic originin soil surface layers. Humin consists ina cluster of humic and non-humic materials. ${ }^{8}$ Humic substancesdirectly interfere with the plant metabolism, due to the effects caused on the soil, such as complexation of metals, increase of cation exchange capacity, supply of nutrients,moisture retention ${ }^{9}$ and stimulation equivalent to that provided by plant hormones like auxin, gibberellins andcytokinins. ${ }^{10}$ Recent studies also demonstrate the potential ofhumic acid usein the increment of fertilization efficiency and in the formulation of inoculants andbiofertilizers. ${ }^{11,12}$ Some studies highlight the importance of humic substances forbioavailability of nutrients, ${ }^{13}$ as well as maturity degreeandchemical stability oforganic materialsadded to thesoil. ${ }^{14,15}$

However, the success regarding the commercial application of humic acidsatfield, with the aim toincreasecropproduction, depends on studies to define the product application rate, which varies according to soil conditions and the type of crop that will be benefited. In a study by Baldotto \& Baldotto, ${ }^{16}$ for example, it was verified that the application of humic acids, at concentrations between 15 and $20 \mathrm{mmolL}^{-1}$, in ornamental sunflower seeds cultivated atfield, provides maximum quality efficiency offloral stems (greater lengthand diameteroffloral stemand larger diameter of inflorescence), while the concentration of $37.8 \mathrm{mmolL}^{-1}$ results in larger production (number offloral stems).

Biofertilizers are prepared from organic residues of different origins, under both aerobic and anaerobic conditions. ${ }^{7}$ The proportion between organic residues and water inbiofertilizers is generally around 10 to $50 \%$, respectively.

In the agricultural market, the use of humic andfulvic acidsis in the enhancement stage, with tests of efficiencyonsoiland plants, being of extreme importance to emphasize the cost-benefit ratioof those products when used alone or in combination withthe traditional mineral fertilizers. The biochemical processes involved in the humus formationare not yet well understood. There are many doubts and little consensus regarding the process generically defined as humification. ${ }^{12}$ Despite that, many studies have shown the increment of crop productionefficiencywith the application of humic and fulvic acids. ${ }^{7,11}$ In view of the above, it is necessary to carry out new evaluations concerning nutrient availability in the soilfrom the application of humic substances, targeting the best system for management of those products, mainly for the Cerrado region, where the soils arenaturally infertile, which generates great costs for the farmerrelative to nutrient replenishment. Therefore, the use ofhumic substances can represent a promising source for chemical composition or maintenance of the soil profile.

\section{Acknowledgments}

None.

\section{Funding}

None.

\section{Conflicts of Interest}

Author declares that there is no conflicto of interest

\section{References}

1. Tavares RLM. Chemical and Biological Attributes of Soils Under Different Ecosystems and Added Soybean Plant Material. Faculty of Agrarian and Veterinary Sciences: Universidade Estadual Paulista; 2010.134 p.

2. Ceccanti B, Alcaniz JM, Gispert M, et al. Characterization of Organic Matter from Two Different Soils By Pyrolysis-Gas Chromatography and Soelectro focusing. Soil Science. 1986;142:83-90.

3. Tate Iii RL. Ecosystem Management and Soil Organic Matter Level. In: Wiley J, Sons Inc, editors, Soil Organic Matter. 1987. p. 260-280.

4. Andreux F. Humus in World Soil. In: Piccolo A, editor. Humic Substances in Terrestrial Ecosystems. Amsterdam: Elsevier; 1996. p. 45-100.

5. Canellas LP, Zandonadi DB, Médici LO, et al. Bioactivity of Humic Substances: Action on Plant Development and Metabolism. In: Canellas LP, Santos GA, editors. Humosphere: Preliminary Treatise on the Chemistry of Humic Substances. Campos Dos Goytacazes: Ccta, Uenf; 2005. p. 224-243.

6. Santos GA, Camargo FAO. Fundamentals of Organic Matter: Tropical and Subtropical Ecosystems. Porto Alegre: Genesis. 1999;69-90.

7. Baldotto MA. Redox Properties and Functional Groups of Humic Acids. North Fluminense State University "Darcy Ribeiro", Campos Dos Goytacazes; 2006. 100 p.

8. Rice JA, Maccarthy PA. Model of Humin. Environmental Science and Biotechnology, New Orleans. 1990;24:1875-1877.

9. Rocha JC, Rosa AH. Aquatic Humic Substances: Interactions With Metallic Species. São Paulo,UNESP. 2003.120 p

10. Caron VC, Graças JP, Castro PRC. Soil Conditioners: Humic and Fulvic Acids. Piracicaba: Esalq-Library Division; 2015.

11. Marques RB, Canellas LP, Silva LG, et al. Promoting Rooting of Sugarcane Microtolets by the Joint Use of Humic Substances and Diazotrophic and Endophytic Bacteria. Brazilian Journal of Soil Science, National Soil Research Center. 2008;32:1121-1128.

12. Baldotto LEB, Baldotto MA, Gontijo JB, et al. Acclimatization of Orchids (Cymbidiumsp.) In Response to the Application of Humic Acids. Rural science. 2014;44:830-883.

13. Moral R, Moreno-Caselles J, Perrez-Murcia MD, et al. Characterization Of The Organic Matter Pool In Manures. Bioresource Technology. 2005;96:153-158. 
14. Mondini C, Sanches-Monedero MA, Sinicco T, et al. Evolution of Extracted Organic Carbon and Microbial Biomass as Stability Parameters in Lignocellulosic Waste Composts. Journal of Environmental Quality. 2006;35:2313-2320.

15. Torres JLR, Pereira MG. Effect of Potassium in Vegetable Waste of Cover Plants in the Cerrado. Brazilian Journal of Soil Science. 2008;32:1609-1618.
16. Baldotto MA, Baldotto LEB. Corn Yield in Field Conditions in Response to the Application of Humic Acids in the Absence and Presence of Liming and Mineral Fertilizer. Analiferbium. 2014. 